\title{
The Effect of Coaching and Mentoring Programs to Improve Students Competencies: Case Study of Beastudi Etos Scholarship
}

\author{
Purwa Udiutoma, S.T., Yulya Srinovita*, S.Si \\ Makmal Pendidikan, Indonesia
}

Copyright (C) 2015 Horizon Research Publishing All rights reserved.

\begin{abstract}
Progress of a country largely determined by quality of its human resources and quality of human life is much influenced by educational factors. Chains of poverty absolutely cannot be separated from economic, health and educational factors. Therefore, one effort to break chains of poverty is to provide proper education. Dompet Dhuafa through Beastudi Etos had conducting educational empowerment with provide coaching, mentoring and financial assistance for poor students. With coaching and mentoring, scholarship recipients are expected not only can studying, but also have knowledge, skills and attitudes competency. This research aims to see the effect of Beastudi Etos's coaching and mentoring programs to improve students' competencies. Research methodology used is descriptive analytical by taking samples at five universities. The results showed that Beastudi Etos's coaching and mentoring programs can improve knowledge, skills and attitudes competency of students. Its significantly improve religious values, but less effect to IT skill.
\end{abstract}

Keywords Competency, Coaching and Mentoring, Scholarship, Knowledge, Skills, Attitudes

\section{Introduction}

Indonesia is a country has many Human Resources (HR), but the quality of its human resources is still lower than other countries at similar stages of development. Being a strength of the nation, Human Resources (HR) became the main problem of this country. According to the UNDP report 2010, Indonesian Human Development Index indicators (ranked 111 ) is still lower than the ASEAN countries such as Singapore (27), Brunei (37), and Malaysia (57), even lower than Thailand (92) and the Philippines (97). Especially when compared to the states "Macan Asia" such as Japan (11), South Korea (12) or Hong Kong (21). The quality of human resources is exacerbated by the depravity of the mentality of the population which is showed in the 2010 Corruption
Perceptions Index which is published by the Transparency International. When a neighboring country, Singapore became the 'best' with Denmark and New Zealand, Indonesia ranks at number 110 . besides, according to the RI Police report, during 2010, there was a criminal offense in Indonesia each interval of 1 minute 54 seconds.

Global competition requires the availability of qualified human resources. Human Resources is required to have professional skills, high technical and managerial creativity and creativity which are sensitive to changes, keep tighter control system by improving the discipline and work ethic, as well as ready to produce great work with a collective work / team. Based on data from the World Economic Forum, Indonesia's global competitiveness has increased to 44 in the world ranking, but only in the Basic Requirement Indonesia was ranked 60 (including the fulfillment of basic education and health are only ranked at 62).

Human Resources is the basic capital construction which consists of a quantitative dimension, namely the number and structure of population and qualitative dimensions of quality of life for residents. Kualitas human resources quality is critical success factors of development and progress of a nation as has been demonstrated by several countries known as the World Bank "The East Asian Miracle". Asian economic revival that promote economic progress spectacularly are not relying on abundant natural resources or the easily available of manpower. The key is human capital investment that will have a huge impact on economic growth in the future. It is need the improvements planned and integrated to produce the qualified human resources and this is where, the education plays an important role. The problem of knowledge, understanding, character and mentality can not be solved only with the BLT, autocratic policies or construct the physical building. However, education will shape the attitude and fighting spirit as well as important personal capacity in order to improve the competitiveness of communally.

The development of a global world confronts the world of education on a number of strategic challenges, ranging from efforts to achieve education for all people to demand changes 
in learning patterns to the times. One of the challenges that must be overcome is the tendency of education as a commodity to develop patterns of privatization and commercialization. When education is used as a commodity, there will be a paradigm shift that would be elitist education, it can only be enjoyed by certain circles who can afford to pay. Ironically, the situation has become a part of the education in Indonesia, especially in the colleges. Learning opportunities elementary school in Indonesia have been parallel to the neighboring countries, however, the college enrollment rate is only $18 \%$ clearly still far behind. Whereas college graduates who had very expected to provide a snowball effect improvement in the quality of Indonesian human resources through the implementation of Tri Dharma College. In quality, the universities in Indonesia is not able to penetrate the top 200 world universities, its still lower when compared to the universities in HongKong, Japan and Singapore are already in the top 30 .

Dompet Dhuafa (DD) as the largest Lembaga Amil Zakat (LAZ) in Indonesia saw a gap in the strategic line. Students are human resource strategic elite to manipulate the cultural and structural changes. It is said to be elite because the proportion is only $2 \%$ of the total population of Indonesia. Provision of higher education not only can improve self welfare and family of college graduates, but it can provide a positive impact on policies that favour the community. A variety of educational empowerment programs have been undertaken, one of which program that directly target potentially to the poor students is Beastudi Etos program.

The Beastudi Etos program is a scholarship program for the potential students but have limited economic in eleven State Universities (PTN) in Indonesia, that are: Andalas University (UNAND), Indonesia University (UI), Bogor Agricultural University (IPB), Institute of Technology Bandung (ITB), Padjadjaran University (UNPAD), Diponegoro University (UNDIP), Gajah Mada University (UGM), Universitas Brawijaya (UNIBRAW), Airlangga University (UNAIR), Institute of Technology of March (ITS), and Hasanuddin University (UNHAS). The assistance given is the cost of going to college, the first and second semester of tuition, dormitory accommodation for three years, an allowance of Rp 400,000.00 - 450,000.00 per month for three years, and some self- development training.

Rationale designed Beastudi Etos program is most of the potential of the poor students are less expressed to continue their study to university level, tuition fees are not affordable and the need for systematic efforts to build mental and character of the next generation. To answer these challenges, in order to produce high-quality graduates, composed boarding coaching system that includes strategic HR domains which includes religious, academic, social and personal development. The program is expected to establish an independent human resources and excel as an effort to break the chains of poverty devil. Not only provide assistance, education financing, and student dormitories, Beastudi Etos also provide guidance and assistance to the grantee (commonly known as etoser) in order to have a set of competencies to be able to perform.

This study is purpose to determine the effect of Beastudi Etos's coaching and mentoring programs to improve Etoser competency to produce graduates HR who excellnce and independent. The evaluation criteria is using three aspects of competence, that are: knowledge, skills and attitudes that are appropriate to the business process Beastudi Etos program. By knowing the level of influence of coaching and mentoring Beastudi Etos programs of the student competency achievement, it is expected to get obtain recommendations for improvement programs. In addition, this best practice can certainly make recommendations to various stakeholders such as DIKTI, education institutions, student dormitories and managers in the management scholarship and the effective coaching.

\section{Methodology}

Students receiving Beastudi Etos (hereinafter referred etoser) came from poor families and have baseline characteristics lacking in confidence but have a strong desire to improve themselves and their families alive. Beastudi Etos program, besides providing financial assistance that includes education first year tuition and stipend for 3 years, also provides boarding facilities and coaching and mentoring students for etoser. Etoser spread across 11 State College (PTN) in 9 cities in Indonesia. Due to the limitations of the study, sampling was conducted at 5 universities in 5 cities, namely Indonesia University (UI) in Depok, Bogor Agricultural University (IPB) in Bogor, Diponegoro University in Semarang, UB (Unibraw) in Malang and Makassar University (UNHAS). The reasons for selecting the PTN are a representation etoser number, area and campus characteristics.

Etoser number from 5 PTN above is 241 as much as students or $62.44 \%$ of the total 389 etoser in Indonesia. The sufficient numbers represent Andalas University, Institute of Technology Bandung, Padjadjaran University, Institute of Technology of March and Airlangga University Etoser is not too much. Gadjah Mada University (UGM) Etoser in Yogyakarta is actually quite a lot, but the representation of Central Java etoser already represented by Undip. In addition, the characteristics of the campus, UI and UGM is similar the 3 top campuses in Indonesia highly academic culture. IPB is representing West Java with scientific specialization. Unibraw is representing the campus in East Java and Unhas is representing campus outside Java.

The sampling technique used for respondents is Convenience sampling combined with purposive sampling, Where the sampling technique will select a more easily found, but it have to meet certain criteria. The size of the minimum number of samples (n) is obtained by using the Slovin formula, ie: $n=\frac{N}{1+N e^{2}}$ 
$\mathrm{N}$ is the total population of 241 etoser from 5 PTN and presentation of leeway because of sampling error (e) is $5 \%$ $(0.05)$. Based on the formula above, the minimum number of samples in this study were 151 respondents (rounding up from 150.39). For thorough research, respondents were chosen as many as 163 students. Data collection was conducted in May 2011 with questionnaires and field observations. Unstructured interviews are also conducted towards the program in the central Beastudi Etos and in each region in order to get the good findings. Before the study was conducted, it has also been analyzed secondary data from internal programs, especially Standard Operating Procedure (SOP) Beastudi Etos Program.

To determine the influence of training and mentoring Beastudi Etos programs, this study requires a number of criteria and competence indicators. Based on the literature review, it can be concluded that competency is a statement of what a person should do in the activity to demonstrate the knowledge, skills and attitudes that appropriate to the required standard. That is to determine the level of the person competence, there are three main criteria that need to be seen, that are knowledge, skills and attitudes. More research needs indicators for each criterion. Qualitative description without indicators actually able to be done by taking the definition of each criterion, but the description will be less deep and less scalable. Therefore, it is need indicator for each criteria which is appropriate to the standard Beastudi Etos program.

For the competence of knowledge, in the domain of academic curriculum development mentioned seven indicators, namely the ability to read, write, literacy, communication, time management, academic planning and critical thinking. While the in SKL curriculum result, indicators of academic domain into a GPA above 3:00, the number of compulsory subjects are taken, English language ability, the ability to write scientific work, critical thinking and academic planning. Communication ability and time management more identic then skills. literacy skills is integrated with the ability to read. The number of compulsory subjects are not included in the indicator because it depends on the campus curriculum so that the target is different in each campus. The ability to write scientific work is developed into a culture of academic and scientific attitude. Retrieved 8 (eight) indicators of knowledge competencies, namely academic planning, GPA above 3:00, English, scientific attitude, culture of reading, writing culture, academic culture and critical thinking.

For competency skills in training curriculum self-development domains mentioned eleven indicators, namely the self-motivation skills, IT, leadership, managerial, communication, self-concept, strategic planning, reading, writing, entrepreneurship and managing the network. While the results of SKL curriculum, a domain indicator develops itself into economic activity, the activity organization, writing skills, reading, communication, IT and achievement motivation. Literacy is more identic then knowledge competence. Economic activity is integrated with entrepreneurial skills. Activities of the organization are integrated in leadership skills. Self-concept and strategic planning are integrated into self-development. Skills motivate themselves is as same achievement motivation. Retrieved 8 (eight) indicators of competency skills, ie self-development skills, managerial, communication, leadership, managing the network, IT, entrepreneurship and achievement motivation.

For attitude competence, Beastudi Etos training domain represents the religious domain and social domains, but indicator in curriculum is too specific such as faith, worship, memorizing Quran and understanding a variety of jurisprudence that does not describe attitude definition. Therefore for the attitude competence indicator is developed from competency standards required to etoser attitude. First, Beastudi Etos provides financial assistance to students in the hope of helping etoser independence. In this case the etoser is expected not forget the place started and forget themselves that they could continue their studt because of the financial assistance community. Etoser is expected to always be grateful and feel pretty (qona'ah). Second, the source of financial assistance is from ZISWAF fund program is loaded with Islamic values. In this case etoser is expected to learn and practice the Islamic values and ZISWAF blessings are continues. Etoser is expected to have Islamic values, perform an Islamic charity and continue to assess the Qur'an. Daily training in dormitories focus on ensure this. Third, Beastudi Etos is empowerment education program that continuously to rotate the wheel usefulness. Etoser is emphasized to contribute to their environment. Etoser is expected to share knowledge, have high social life and can live in a society well. From the description above, obtained 8 (eight) attitude indicator accordance the standard of competence required program, ie an attitude of gratitude, feeling pretty, Islamic values, an Islamic charity, reviewing the Qur'an, share knowledge, social attitudes and social life.

For each of the indicators are measured achievement through a questionnaire with Likert scale weighting method, where the performance is measured by comparing the total value of achievement (realization) with a total expected value. The scale is used the percent (\%) with the index information in accordance with the following indicators: (1). 0 - $40 \%$ No effect; (2). 40 - $60 \%$ less influential; (3). 60 $80 \%$ Influential; (4). 80 - $100 \%$ Very influential

\section{Result}

Beastudi Etos was established in 2003. Vision of Beastudi Etos is leading the way in shaping the excellent and self-generation. The explanation of this vision is: (1) Foremost, it means to get ahead, be a pioneer investment program. Human resources and not lagging behind in the implementation of the program management system; (2) In form, it means in an effort to provide guidance and direction in order to produce output that corresponds to the potential per individual, not to be uniform in pattern and output but still no clear planning and a culture of discipline; (3) 
Excellent Human resources, means a better value in terms of awareness, achievement and productivity within the scope of religion, academic; (4) Independent human resource, meaning that human resources can be independent, not dependent on others, both financially, thoughts and attitudes, as well as powerful and capable of empowering.

Beastudi Etos outlines vision into 4 missions are: (1) implementing quality management, (2) implement curriculum based coaching Beastudi Etos competence, (3) establish and optimize the network Beastudi Etos, and (4) optimize the role of Beastudi Etos human resources in community empowerment.

Theoretically, the existence of the coaching will give effect to the increased competence, but it can not be sure how much. Coaching and mentoring Beastudi Etos also should give effect to the increased etoser competence, it just needs to be studied how significant. It will be presented and discussed research data on the effect of coaching and mentoring achievements Beastudi Etos towards the improvement etoser competence as following.

From the table 1, it can be showed that in general coaching and mentoring is done by Beastudi Etos impact on the achievement of indicators of knowledge competencies etoser. However, this effect was not significant for etoser in the UI and UNIBRAW, whereas in two academic campus is quite high. The biggest impact of coaching and mentoring Beastudi Etos in knowledge competence is found in critical thinking indicators, academic plans, reading culture and scientific attitude. While for the indicator ability to write and English less influence. It means that coaching and mentoring Beastudi Etos towards improving the competence of knowledge is still on the surface, such as the establishment of a scientific mindset and attitude as well as awareness of the importance of academic planning for students. And, for the development competencies are more specifik, campus more holding role. This analysis is corroborated by the fact that the basis of academic achievement, including in various science competitions, etoser in UI and UNIBRAW relative is the best then IPB, UNDIP, and UNHAS.

There are some interesting notes from the table 1 . Coaching and mentoring in IPB was quite an impact on etoser IPB English competency when the other areas got less the effect. In practicing, coaching English to IPB is supported by institutions in the provision of teaching staff. Another interesting data is that coaching and mentoring in Undip and IPB turns giving effect to improve the current culture of writing etoser in other areas that had less influence. At the two campuses, the program manager is developing writing every month even require etoser to make posts. Not surprisingly, there have been published a book produced by the alumni etoser of the two campuses. This is showed that the influence of coaching and mentoring the etoser competencies also determined by the policies of program manager, and the availability of facilities. Furthermore, for competency skills, coaching and mentoring is done by Beastudi Etos gives impact on the achievement of etoser competence indicators skills. The higher influenced is more highly then the indicators achievement of knowledge competencies. The biggest impact of coaching and mentoring skills Beastudi Etos is found in the indicators of achievement motivation, leadership skills, managing the networks and communication. And for the indicator technology competence is less impact. This is showed that coaching and mentoring Beastudi Etos towards the improvement of skills competence are still more focused on interpersonal skills, such as leadership and communication. And for the technical skills is more personal, not sufficiently accommodated. Organizing and coaching routine boarding in the hostel is very supportive for the increasing a variety of interpersonal skills, such as Kultum and the formation of the organization dormitories. Not to the variety of activities and events organized also will certainly improve interpersonal skills. Here the data's significant influence Beastudi Etos coaching and mentoring skills to increase the etoser competence.

Table 1. The effect of coaching and mentoring to the indicators of knowledge competencies

\begin{tabular}{|c|c|c|c|c|c|c|c|}
\hline No & Indicator & UI & IPB & Undip & Unbraw & Unhas & Average \\
\hline 1 & Academic Plan & $51,5 \%$ & $71,3 \%$ & $79,8 \%$ & $62,9 \%$ & $72,1 \%$ & $67,5 \%$ \\
\hline 2 & GPA above 3,00 & $56,3 \%$ & $59,7 \%$ & $77,0 \%$ & $59,8 \%$ & $75,0 \%$ & $65,6 \%$ \\
\hline 3 & English & $55,7 \%$ & $66,7 \%$ & $47,1 \%$ & $33,0 \%$ & $59,8 \%$ & $52,5 \%$ \\
\hline 4 & Scientific attitude & $59,4 \%$ & $66,2 \%$ & $78,3 \%$ & $66,3 \%$ & $62,7 \%$ & $66,6 \%$ \\
\hline 5 & Reading culture & $59,8 \%$ & $76,6 \%$ & $69,1 \%$ & $62,1 \%$ & $68,8 \%$ & $67,3 \%$ \\
\hline 6 & Writing culture & $51,1 \%$ & $67,6 \%$ & $71,3 \%$ & $41,2 \%$ & $52,0 \%$ & $56,6 \%$ \\
\hline 7 & Academic culture & $53,6 \%$ & $64,8 \%$ & $73,6 \%$ & $60,0 \%$ & $69,6 \%$ & $64,3 \%$ \\
\hline 8 & Critical thinking & $68,0 \%$ & $75,6 \%$ & $76,2 \%$ & $65,4 \%$ & $57,5 \%$ & $68,5 \%$ \\
\hline & Average & $56,91 \%$ & $56,9 \%$ & $68,6 \%$ & $71,5 \%$ & $56,3 \%$ & $63,6 \%$ \\
\hline
\end{tabular}


There are some interesting notes from the table 2 . Coaching and mentoring in Undip gives influence on leadership skills and network management etoser Undip with no significant difference in performance compared to other regions. In Undip, leadership competencies strengthened by establishing the existence etoser through Student Families' party. Party system in Undip student directly entrust the the etoser's party Undip which has logo Beastudi Etos obtain a second vote majority with the highest representatives who accupy in the Senate. Etoser Undip also has a networking with the media so there are many events that are successfully covered by the media, both megazine and electronic, local and national. Other interesting data is that coaching and mentoring in Unhas and IPB turns giving effect to improve entrepreneurial capacity etoser when another areas is less. At the two campuses, the program manager is to develop entrepreneurs as an effort to establish independent human resources. Not surprisingly Beastudi Etos in two the region existing business units etoser and alumni who produce and market the product to the market. It is showed that the influence of coaching and mentoring to the etoser competencies also determined by the creativity and initiative of program managers to develop the potential etoser.

Furthermore, for the attitudes competence, in general coaching and mentoring is done by Beastudi Etos gives significant influence on the achievement of competence indicators etoser attitude. The influence is more highly than achievement of indicators of knowledge competencies and skills. The biggest effect of coaching and mentoring Beastudi Etos in the attitude competence is found in the indicator that relate to religion domain and social. It is showed that rainingt and mentoring Beastudi Etos towards improving the attitude competence gives significant influence on the implementation and understanding of religious and social attitudes. Daily routine coaching in a dorm is proved able to create a better attitude.

Table 2. The effect of coaching and mentoring to the indicators of competency skills

\begin{tabular}{|c|c|c|c|c|c|c|c|}
\hline No & Indikator & UI & IPB & Undip & Unbraw & Unhas & Average \\
\hline 1 & Self-development & $58,8 \%$ & $73,8 \%$ & $77,9 \%$ & $57,6 \%$ & $70,0 \%$ & $67,6 \%$ \\
\hline 2 & Managerial skill & $65,3 \%$ & $76,9 \%$ & $75,9 \%$ & $61,9 \%$ & $60,0 \%$ & $68,0 \%$ \\
\hline 3 & Communication Skill & $64,3 \%$ & $86,1 \%$ & $83,9 \%$ & $61,3 \%$ & $67,7 \%$ & $72,7 \%$ \\
\hline 4 & Leadership Skill & $74,7 \%$ & $78,2 \%$ & $85,1 \%$ & $69,2 \%$ & $70,2 \%$ & $75,5 \%$ \\
\hline 5 & Networking Skill & $72,9 \%$ & $74,7 \%$ & $86,2 \%$ & $69,6 \%$ & $71,9 \%$ & $75,1 \%$ \\
\hline 6 & IT Skill & $39,6 \%$ & $57,9 \%$ & $59,3 \%$ & $44,2 \%$ & $56,9 \%$ & $51,6 \%$ \\
\hline 7 & Entrepreneurship & $54,6 \%$ & $76,0 \%$ & $60,9 \%$ & $52,4 \%$ & $76,5 \%$ & $64,1 \%$ \\
\hline 8 & $\begin{array}{l}\text { Motivation to achieve } \\
\text { something }\end{array}$ & $69,4 \%$ & $79,5 \%$ & $88,5 \%$ & $71,4 \%$ & $71,9 \%$ & $76,1 \%$ \\
\hline & Average & $62,46 \%$ & $62,5 \%$ & $75,4 \%$ & $77,2 \%$ & $61,0 \%$ & $68,2 \%$ \\
\hline
\end{tabular}

Table 3. The effect of coaching and mentoring to the indicators of attitude competence

\begin{tabular}{|c|l|c|c|c|c|c|c|}
\hline No & \multicolumn{1}{|c|}{ Indicator } & UI & IPB & Undip & Unbraw & Unhas & Average \\
\hline 1 & Gratitude Attitude & $78,4 \%$ & $64,9 \%$ & $87,2 \%$ & $77,1 \%$ & $88,2 \%$ & $79,2 \%$ \\
\hline 2 & Feeling sufficient & $63,3 \%$ & $72,7 \%$ & $62,8 \%$ & $63,1 \%$ & $67,6 \%$ & $65,9 \%$ \\
\hline 3 & Religious value & $83,7 \%$ & $87,2 \%$ & $90,8 \%$ & $79,6 \%$ & $82,7 \%$ & $84,8 \%$ \\
\hline 4 & Islamic charity & $70,1 \%$ & $77,6 \%$ & $87,4 \%$ & $77,1 \%$ & $74,3 \%$ & $77,3 \%$ \\
\hline 5 & Recite Qur'an & $75,0 \%$ & $79,8 \%$ & $67,8 \%$ & $60,2 \%$ & $62,4 \%$ & $69,0 \%$ \\
\hline 6 & Sharing knowledge & $74,5 \%$ & $80,3 \%$ & $77,0 \%$ & $68,3 \%$ & $68,0 \%$ & $73,6 \%$ \\
\hline 7 & Sikap Social attitude & $74,8 \%$ & $73,7 \%$ & $79,3 \%$ & $67,6 \%$ & $61,5 \%$ & $71,4 \%$ \\
\hline 8 & Society relationship & $72,2 \%$ & $82,7 \%$ & $78,2 \%$ & $76,2 \%$ & $74,3 \%$ & $76,7 \%$ \\
\hline & Average & $73,97 \%$ & $74,0 \%$ & $77,3 \%$ & $78,8 \%$ & $71,2 \%$ & $72,4 \%$ \\
\hline
\end{tabular}


Table 4. The recapitulation of the effects of coaching and mentoring by competence indicators

\begin{tabular}{|c|c|c|c|}
\hline Competence & Indicators & Average Achievement & Description \\
\hline \multirow{8}{*}{ Knowledge } & Academic Plan & $67,5 \%$ & Influential \\
\hline & GPA above 3,00 & $65,6 \%$ & Influential \\
\hline & English & $52,5 \%$ & Influential \\
\hline & Scientific attitude & $66,6 \%$ & Influential \\
\hline & Reading culture & $67,3 \%$ & Influential \\
\hline & Writing culture & $56,6 \%$ & Influential \\
\hline & Academic culture & $64,3 \%$ & Influential \\
\hline & Critical thinking & $68,5 \%$ & Influential \\
\hline \multicolumn{2}{|r|}{ Average } & $63,6 \%$ & Influential \\
\hline \multirow{8}{*}{ Skill } & Self-development & $67,6 \%$ & Influential \\
\hline & Managerial skill & $68,0 \%$ & Influential \\
\hline & Communication Skill & $72,7 \%$ & Influential \\
\hline & Leadership Skill & $75,5 \%$ & Influential \\
\hline & Networking Skill & $75,1 \%$ & Influential \\
\hline & IT Skill & $51,6 \%$ & Less Influential \\
\hline & Entrepreneurship & $64,1 \%$ & Influential \\
\hline & Motivation to achieve something & $76,1 \%$ & Influential \\
\hline \multicolumn{2}{|r|}{ Average } & $68,2 \%$ & Influential \\
\hline \multirow{8}{*}{ Character } & Gratitude Attitude & $79,2 \%$ & Very Influential \\
\hline & Feeling sufficient & $65,9 \%$ & Influential \\
\hline & Religious value & $84,8 \%$ & Very Influential \\
\hline & Islamic charity & $77,3 \%$ & Very Influential \\
\hline & Recite Qur'an & $69,0 \%$ & Influential \\
\hline & Sharing knowledge & $73,6 \%$ & Influential \\
\hline & Sikap Social attitude & $71,4 \%$ & Influential \\
\hline & Society relationship & $76,7 \%$ & Influential \\
\hline \multicolumn{2}{|r|}{ Average } & $72,4 \%$ & Influentisl \\
\hline
\end{tabular}

Table 5. Recapitulation of the effects of coaching and mentoring by campus

\begin{tabular}{|c|c|c|c|c|c|c|}
\hline Competence & UI & IPB & Undip & Unbraw & Unhas & Rata - rata \\
\hline Knowledge & $56,9 \%$ & $68,6 \%$ & $71,5 \%$ & $56,3 \%$ & $64,7 \%$ & $63,6 \%$ \\
\hline Skill & $62,5 \%$ & $75,4 \%$ & $77,2 \%$ & $60,9 \%$ & $68,1 \%$ & $68,3 \%$ \\
\hline Character & $74,0 \%$ & $77,3 \%$ & $78,8 \%$ & $71,1 \%$ & $72,4 \%$ & $74,7 \%$ \\
\hline Rata - rata & $64,4 \%$ & $73,8 \%$ & $75,8 \%$ & $62,8 \%$ & $68,4 \%$ & $69,1 \%$ \\
\hline
\end{tabular}

From the table 4 it can be showed that coaching and mentoring Beastudi Etos is affected to the increasing of etoser competence, either knowledge, skills and attitudes. As continuously, the most powerful is influence on improving the attitude competence, skills competencies, and the knowledge competence. Coaching and mentoring Beastudi Etos gives effect to the increasing of etoser religious values. But, for some specific competencies and applicables as English proficiency, writing, and the use of information technology coaching and mentoring Beastudi Etos less influence. This is certainly a special note, because these competencies are needed in the world work.
From the table 5 shows that the mapping of the campus, where coaching and mentoring Beastudi Etos di UI and Unibraw are still less influence to the improvement etoser competence knowledge. To be able to understand that the dynamics of UI combined with high academic cultures which cause the major role of the learning, knowledge and skills at collage. The hostel Beastudi Etos tends to strengthen the attitude competence, but for the more developed actualization is on campus. Therefore, despite of in the hostel is relative calm; UI etoser is quite competitive and known on campus, etheir academic or non-academic. To Beastudi Etos Malang, the data above reveal that still need a lot of 
improvement in coaching and mentoring etoser Unibraw. Various achievements of etoser Unibraw unproved significantly are influenced by coaching and mentoring Beastudi Etos. On the other hand, the implementation of the curriculum, and coaching and mentoring Beastudi Etos Bogor area and Semarang have a positive influence on the improvement of etoser competence. IPB Etoser is excellent in mentoring development patterns based on their interests and talents, etoser Undip is excellent in creativity and character education. This variety of added value should be transmitted to other areas so that performance coaching and mentoring can be increased.

\section{REFERENCES}

[1] Lubis, Khairul Akhir. 2008. Pengaruh Pelatihan dan Motivasi Kerja terhadap Kinerja Karyawan PT. Perkebunan Nusantara IV (Persero) Medan (Medan : Tesis untuk memperoleh gelar Magister Sains dalam Program Studi Ilmu Manajemen, Sekolah Pascasarjana USU)

[2] Muslich, Masnur. 2011. Pendidikan Karakter Menjawab Tantangan Krisis Multidimensional. Jakarta : Bumi Aksara.

[3] Program Beastudi Etos. 2006. Standard Operating Procedures. Bogor : Beastudi Etos.

[4] Schwab, Klaus. 2011. The Global Competitiveness Report 2010 - 2011 : Highlights. Geneva : World Economic Forum.

[5] Transparency International. 2010. Corruption Perception Index 2010. Berlin : Transparency International. 